\title{
Middle Level Students' Goal Orientations and Motivation
}

\author{
Emmanuel Mensah ${ }^{1}$, George Atta $^{1}$ \\ ${ }^{1}$ University of North Dakota, USA \\ Correspondence: Emmanuel Mensah, University of North Dakota, USA
}

Received: December 22, 2014

Accepted: December 29, 2014 Online Published: February 5, 2015

doi:10.11114/jets.v3i2.617

URL: http://dx.doi.org/10.11114/jets.v3i2.617

\begin{abstract}
The study used a phenomenological lens to explore middle level classroom goal perceptions and classroom experiences that were pivotal in motivating students to achieve their learning goals. A total of 46 participants (31 students and 15 teachers) from two middle schools in a Midwestern city participated in focus group discussions and one-on-one interview sessions respectively. Findings indicated that teachers endorsed long-term goals with mastery emphasis. However, students' classroom goals were more performance and less mastery oriented. In addition, thematic analyses of participants' perspectives showed that: classroom lessons that are more engaging, teachers' positive disposition and personality, personal connection with learning experience, application of varied instructions, and supportive teacher relationships are key classroom experiences in driving middle level students to achieve their learning goals. Implications for middle level classroom instructions and future research directions have been discussed.
\end{abstract}

Keywords: motivation, middle level learners, goal theory, middle level classroom goals, performance goal, and mastery goal.

Students' goal perspectives constitute a foundational structure in the construct of classroom motivation, engagement, and achievement (Midgley \& Urdan, 2001). Literature on achievement goals widely reports that mastery goal structure has proximal influence on students' intrinsic motivation, adaptive learning behavior, and task engagement (Elliot, 1999; Deemer, 2004). However, performance goal structure has negative relationships with students' intrinsic motivation and academic self-concepts (Muraya \& Elliot, 2009; Meece, 2003). Theoretical perspectives suggest that performance and mastery goal pursuits, as well as multiple goal perspective are significant in middle level classrooms (Ames, 1992; Harackiewicz, et al., 2002; Stipek, 2002). While evidence shows that elementary school teachers are more likely to use instructional practices that emphasize mastery goals than middle school teachers (Midgley, Anderman, \& Hicks, 1995), it is not clear the nature of classroom goals that shape middle level learning environment.

In the middle level classroom, goal pursuits of students have important implications for classroom instructions and how students respond to academic tasks (Meece, Anderman, \& Anderman, 2006; Wolters \& Daugherty, 2007; Meece, 2003). Thus, students' classroom goal pursuits and motivational tendencies are interwoven, factors which tend to shape the quality of classroom experiences, students' cognitive functioning, and the overall achievement outcomes (Wentzel \& Wigfield, 2007; Ryan \& Patrick, 2001; Anderman \& Maehr, 1994). However, the nexus between goal pursuits and motivational tendencies of middle level students marks a complex relationship, mediated by the social, emotional, moral, psychological, and biological contexts that characterize their learning environments (William-Boyd, 2003). The implications are that for educators who work with middle level students, understanding the goals that students pursue and the motivational tendencies that drive these goals should be of a principal concern (Daniels \& Steres, 2011). However, in framing educators' understanding of students' goal pursuits and motivation in the literature, less amount of contextual information has been drawn from the "voices" of middle level students and the teachers who teach them. To contribute to the depth of educators and researchers' understanding of the narratives of middle level students' goal pursuits and their classroom motivation, we explored the perspectives of middle school students and teachers in one school district.

\section{Literature Review}

\subsection{Improving Middle Level Education in the United States}

Since its inception in the 1960s, the middle level education movement has been a subject of series of structural and ideological reformations (Lounsbury, 1997). The cause to re-examine middle level education during this period was 
necessitated by the observed high dropout rate among junior high school students before entering high school (Casas, 2011). Studies attributed the early and the high dropout rates in the late 1960s and 1970s to the structural inadequacies and the lack of clear educational mission within the junior high school programs (Haselhuhn, Al-Mabuk, Gabriele, Groen, \& Galloway, 2007).The programs of the junior high schools failed to meet the intellectual, social, emotional, and physical needs of the young adolescents (Casas, 2011; Hlebowitsh, 2001). The late 1980s, therefore, saw a paradigm shift from the junior high school model to the concept of middle level education, with the aim of increasing commitments to meet the developmental needs of young adolescents (Casas, 2011; Eccles, Lord, \& Midgley, 1991). Meanwhile, except for the grade configurations, the middle level education reform movement of 1980s was a failure at the nationwide level in terms of specific provisions to stimulate important changes to the curriculum, programs, and practices to improve schools for the young adolescents (Casas, 2011; Hlebowitsh, 2001). A task force on education of young adolescents was then charged by Carnegie Council to look into the reasons why middle schools and junior high schools had failed to meet the needs of the young adolescents. On its part, The National Middle School Association (NMSA), which was founded in 1973, presented and published a position paper entitled This We Believe in 1982 to publicize the need to improve the education of the young adolescents (Knowles \& Brown, 2000). Part of its findings which had been published in 1989 as the Turning Points: Preparing Youth for the $21^{\text {st }}$ Century, the Carnegie Council indicated large enrollments, ineffective student-adult (teachers, administrators, and counselors) relationships, and misplaced curriculum and instructional strategies as some of the major issues that needed attention (Knowles \& Brown, 2000).The council, therefore, recommended a completely transformed middle grade school to cope with the requirements of the new era and to provide students with opportunities to fulfill their youthful promise (Knowles \& Brown, 2000). Such initiatives garnered efforts to address the needs of young adolescents by strengthening the relationships amongst schools, families, the community, and health organizations (Casas, 2011). Although contemporary middle level education continues to face similar challenges, proponents argue that middle schools have experienced significant structural changes necessary to meet adolescents' educational needs (Casas, 2011; NMSA, 2003).

\subsection{The Middle Level Student}

The middle level student is a young adolescent with a probable age range of 10-15years who experiences complex transitions of emerging independence and constructing attitudes, values, and habits of the mind (NMSA, 2003). Middle level students tend to draw comparisons with peers on physical, cognitive, and social features (Eccles \& Wigfield, 1997). Middle level students are typically vibrant, alive, curious, energetic, and exciting to be around (Knowles \& Brown, 2000). As they experiment with new roles, new friends, and new ideas, middle level students become obsessed with appearance, body image, and peer acceptance (NMSA, 2003). Middle level students need school environment that demonstrates developmental readiness and educators who celebrate their successes and not criticize their challenges (William-Boyd, 2003). Middle level educators are, therefore, expected to work towards achieving a balance between academic vigor and developmental responsiveness, a balance between seeing students as active learners and acknowledging them as fast changing young adolescents (William-Boyd, 2003).

\subsection{The Middle Level Student Learning Environment}

The motivated middle school student is enthusiastic, active, curious, persistent, and able to cope with challenging situations and setbacks (Skinner \& Belmont, 1993). However, these traits do not exist in a vacuum. The classroom environment should support their development. In this study, we reviewed literature on classroom relationships; students' motivational beliefs; and teachers as classroom motivators.

\subsubsection{Classroom Relationships}

School based social relation gives individuals the chance to develop beliefs, orientations, and values that are consistent with their learning goals (Martin \& Dowson, 2009). Of all the major forms of school based social relationships, teacher support appears crucial (Juvonen, 2007). For students to be successful in school, they need to feel belonged, accepted, valued, and adequate of having the skills and the inner resources to succeed (Kouzes \& Posner, 2002). Knowles and Brown (2000) observed that in staying away from the need for parental approval, young adolescents need to know that someone other than their peers would provide support system for them. High quality relationships allow individuals to learn and internalize the beliefs valued by others within an institution (Wentzel, 1999). Middle level students' sense of teachers' caring, fairness, and commitment influences their active participation in the classroom (Wentzel, 1999). However, students' perception of being treated with disrespect perhaps because of their race or gender affects their classroom behavior and their overall interest in school (Roeser \& Eccles, 1998).

\subsubsection{Students' Motivational Beliefs}

Motivational beliefs and perceptions are relevant to the value students attach to the domain of their achievement capabilities and the teaching methods of teachers (Boekaerts, 2002). Students' motivational beliefs function as a frame that guides their thinking, feelings, and their action in a particular domain (Boekaerts, 2002). These domains may be 
either favorable (positive, optimistic) or unfavorable (negative, pessimistic) (Pintrich, 2001). Favorable motivational beliefs are attached to activities that students tend to be more interested to undertake and activity for which they think they have the necessary competence (Boekaerts, 2002; Bruning \& Horn, 2000). Studies show that students' motivational beliefs are influenced by verbal statements by teachers, parents, and peers (Boekaerts, 2002; Pintrich, 2001). Teachers can help middle level students to develop favorable motivational beliefs by relating the curriculum to students' current interests, future career goals, and skills they find more relevant and interesting (Boekaerts, 2002).

\subsubsection{Teachers as Motivators}

According to Erwin (2004), teachers are the managers in the classrooms who manage the learning space, time, materials, and the mental, physical, and emotional states of individual students. As a motivator, the teacher is expected to inspire students' natural tendencies to learn, grow, and take responsibility of their own learning (McCombs \& Pope, 1994). In the classroom context, what the teacher teaches, supports, values, models, and encourages is significant in student motivation (Davis, 1993). Good and Brophy (1995) contended that modeling, teaching of pro-social behavior, communicating positive expectations, attributes, and social labels, and reinforcing desired behavior enhances classroom motivation. Knowles and Brown (2000) identified the qualities of a motivating teacher as; having the sense of humor to share with students; being flexible in the planning and delivering instructions; having the passion to learn from students; and showing sincere care for the needs of young adolescents.

\section{Theoretical Framework}

Understandings on students' motivation across different contexts are drawn from different theoretical perspectives. A range of contemporary motivation theories have different implications for middle level education. However, in the current study, we drew our theoretical perspectives from the achievement goal theory (Elliot, 1999; Brophy, 2005). Achievement goal theory provides a useful framework for describing the learning environment of middle level classrooms (Meece, 2003; Ames, 1992). Achievement goal theory draws both direct and indirect relational implications among various conditions, such as the classroom context, quality of students' effort and engagement, and students' classroom achievement. Early studies in goal theory contrasted mastery or learning goal and performance or task goal orientations (Brophy, 2005; Elliot, 1999). On one hand, mastery goal orientations are aligned with the inherent desire for students to improve their ability, master a skill, and understand a learning material (Meece, 2003; Anderman \& Midgley, 1997; Elliot, 1999). On the other hand, task goal orientation represents the perspective that the purpose of achieving is for personal improvement and understanding (Andeman \& Midgley, 1997; Elliot, 1999). The dichotomy of these two goal orientations, over the years, has been based on the underling levels of academic value attached to students' classroom task performance and learning (Elliot, Murayama, \& Pekrun, 2011). Thus, achievement goal theorists contend that mastery and performance goals are associated with varying levels of competence-relevant effects, cognition, and behavior (Elliot, 1999).

Along several theoretical and empirical lines of argument, mastery goals are found to convey positive processes and outcomes, while performance goals are more related to a set of negative processes and outcomes (Brophy, 2005; Elliot, 1999). Goal theorists maintain that task goal-oriented students direct their efforts toward mastering skills and knowledge and determine their successes based on their own level of progress (Anderman \& Midgley, 1997). In this case, self-improvement becomes the underlying factor for students' classroom goals from which the inherent qualities of the task, such as its challenges, interest, and enjoyment give internal satisfaction to students (Meece, 2003). Teachers' roles in such an environment are to drive students to internalize the belief that persistence and increasing efforts would lead to improved outcomes. However, in a learning environment in which much emphasis is placed on performance goals, "trying hard" is considered by students as an indication of lack of ability (Deemer, 2004; Meece, 2003). These cause students to exhibit decreased task enjoyment and effort when faced with challenging situations (Elliot, 1999). Such situations can create social comparative concerns, especially when students evaluate their own success or failure in relation to others (Brophy, 2005). For such students, their sense of accomplishment is associated with their ability to demonstrate high ability or avoiding negative judgment from teachers and other students (Meece, 2003). Competing for grades or gaining recognition by students for their performances not only discourages students from taking on challenging experiences, but also it is a disincentive for students to seek help from their colleagues (Anderman \& Midgley, 1997; Meece, 2003; Pintrich \& Schunk, 2002). While the long-term impact of performance goals is unclear, growing evidence suggests that young adolescents benefit the most from classroom environments with a mastery focus (Ames, 1992; Stipek, 2002).

Revisions in achievement goal theory have introduced a multiple goal perspective (Harackiewicz, Barron, Pintrinch, Elliot, \& Thrash, 2002). Proponents of multiple goal perspective argue that students are motivated to engage in school activities for multiple reasons and that combining the unique strengths of both performance and mastery goals can influence students' optimal performance (Harackiewicz, et al., 2002; Deemer, 2004). However, other goal theorists 
contend that multiple goal perspective introduces complexities that relate to goal-coordination abilities of students, the practicality of its application, and the overloading of students' cognitive resources (Brophy, 2005). Notwithstanding, multiple goal perspective as a theoretical position equally presents important classroom implications for middle level students and educators. In a learning environment where emphasis is placed on multiple goal beliefs, teachers may need to use selective goal path by emphasizing performance goals in some contexts, and mastery goals in other contexts (Deemer, 2004). The need for teachers to work with students in maintaining balance between mastery and performance goals may be critical, depending on what makes most significant long-term contribution toward the overall learning outcomes of students.

\section{Method}

\subsection{Purpose and Research Questions}

The study used a phenomenological lens to explore middle level classroom goal perceptions and the experiences that were central in driving students to achieve their classroom goals. Phenomenological research is designed to describe and interpret the phenomenon that is under investigation from a perspective free of hypotheses or preconceptions (Giorgi, 2007). Consistent with the design, the purpose of the study was to describe and interpret students and teachers' classroom goal and motivational perspectives, and to gain understanding of the essence of such perspectives (van Menam, 1990). The study was guided by the following research questions:

1. What classroom goals do middle level students pursue?

2. What classroom goals do middle level teachers emphasize in their teaching?

3. What classroom experiences motivate middle level students to achieve their goals?

\subsection{Study Participants}

The study was conducted in two middle schools in a Midwestern city during in the spring of 2012. The two schools were in the same district and together they served approximately 1,324 students. Enrolments in these two schools were largely Whites. The participants comprised both middle school students and teachers (6-8 grades). The total number of participants was 46 of which 31 were students and 15 were teachers. Of this number, 16 student and 9 teacher participants were from school A and 15 students and 6 teacher participants came from school B. Tables 1 and 2 show summaries of student and teacher participants' demographic information. Purposeful sampling techniques were used to select student and teacher participants. Purposeful sampling "involves particular settings, persons, or events that are deliberately selected for the important information they can provide that cannot be gotten as well from other choices" (Maxwell, 2008, p. 235). Participants were selected because they had experienced the phenomenon of motivation and were willing to share such lived experiences (Leedy \& Ormrod, 2005). Through initial correspondence with administrators of the two schools, contacts were established with teachers who volunteered to participate in the study. Upon obtaining the district and IRB approval, and parental consents, teacher and student participants were selected per their agreement to participate in the study. The selection of student participants was facilitated by their teachers.

Table1. Summary of Student Participants' Background Information

\begin{tabular}{|c|c|c|c|}
\hline Demographics & Identifiable groups & School A & School B \\
\hline \multirow[t]{2}{*}{ Gender } & Male & 7 & 6 \\
\hline & Female & 9 & 9 \\
\hline \multirow{3}{*}{$\begin{array}{l}\text { Grade level group } \\
\text { participants }\end{array}$} & FG: Grade 6 & 5 & 5 \\
\hline & FG: Grade 7 & 6 & 5 \\
\hline & FG: Grade 8 & 5 & 5 \\
\hline \multirow[t]{3}{*}{ Average Age } & Grade 6 & 11 & 11.5 \\
\hline & Grade 7 & 12.5 & 13 \\
\hline & Grade 8 & 14 & 14 \\
\hline \multirow[t]{5}{*}{ Race/Ethnicity } & White & 12 & 13 \\
\hline & Black & 1 & 0 \\
\hline & Hispanic & 1 & 1 \\
\hline & Asian & 1 & 0 \\
\hline & Hawaiian/Native pacific islander & 1 & 1 \\
\hline
\end{tabular}


Table 2. Summary of Teacher Participants' Background Information

\begin{tabular}{|c|c|c|c|}
\hline Participants & Background Information & School A & School B \\
\hline \multirow[t]{2}{*}{ Gender } & Male & 3 & 2 \\
\hline & Female & 6 & 4 \\
\hline \multirow{3}{*}{$\begin{array}{ll}\text { Grade } & \text { level } \\
\text { participants } & \end{array}$} & Grade 6 & 2 & 2 \\
\hline & Grade 7 & 4 & 2 \\
\hline & Grade 8 & 3 & 2 \\
\hline \multirow{3}{*}{$\begin{array}{l}\text { Average years of } \\
\text { teaching }\end{array}$} & Grade 6 & 10 & 5 \\
\hline & Grade 7 & 8 & 10 \\
\hline & Grade 8 & 12 & 6 \\
\hline \multirow[t]{5}{*}{ Race/Ethnicity } & White & 8 & 5 \\
\hline & Black & 0 & 1 \\
\hline & Hispanic & 1 & 0 \\
\hline & Asian & 0 & 0 \\
\hline & American Indian/Alaskan native & 0 & 0 \\
\hline
\end{tabular}

\section{Data Collection}

Teacher participants' perspectives and experiences were explored through one-on-one interviews. Teacher participants were all assigned codes (e.g., AT1, AT2, through AT9 and BT1, BT2, through BT6) to preserve their identity and also to track their comments. Participants answered nine semi-structured questions. Each participant participated in at least, two separate interview sessions at a month time interval period. The first session of the interviews focused on concepts. The concepts were further explored in depth during the second interview sessions (Stake, 2010). Interview sessions lasted approximately 35 minutes. In all, 31 separate interviews were held in the two schools. While some sessions were held after class hours, other sessions took place during participants' free hours. All sessions were tape-recorded, allowing the researcher to take notes and also guided participants into areas in more depth.

With student participants, focus group discussions were designed to solicit their classroom experiences and perspectives using eight semi-structured questions. Six different focus group discussions were held, with three groups from each of the two middle schools. The size of the focus groups ranged between five and six students with mixed abilities. The teachers of the students facilitated the composition of the focus groups. Focus group sessions were held during typical school hours, with each lasting approximately 40 minutes. Student participants were assigned identity codes. These were to facilitate identification of students' quotes and comments for appropriate referencing.

\section{Data Analysis}

We began the data analysis process with verbatim transcription of all tape-recorded data from students' group discussions and teacher interviews. Transcripts were double-checked by reviewing drafts while listening to the tapes. Occasionally, quotes were edited for the purpose of clarity, and those edits were not made when they would change the content, context, or meaning of the participants' words. We used line-by-line coding to generate initial categories (Charmaz, 2011). We studied the coded items to identify similar phrases, relationships amongst categories, and common patterns and relationships that were emerging. The data were further organized around the merging themes. We then drew some assertions based on the themes that had emerged. These assertions were supported with exact quotes from the interview and focus group transcripts which became vital to the rich descriptions of the study, since they preserved the participants' exact words for readers. We used peer debriefing and scrutiny sessions and member checking by engaging peers and academics and sought their feedbacks on tentative interpretations (Lincoln \& Guba, 1985). Also, we documented any preconceived ideas, personal experiences, and biases that could influence the results of the study (van Menam, 1990).

\subsection{Findings}

The study explored middle level classroom goals and experiences that students and teachers considered as motivators that drove students to achieve such goals. We present common themes that emerged from the analyses of both students' focus group and teachers' interview transcripts. In all, seven themes emerged, two themes representing classroom goal pursuits and five themes representing motivators in the middle level classroom. 


\subsubsection{Middle Level Classroom Goals}

The two themes that emerged in regards to middle level classroom goal pursuits were pursuance of good grades and pursuance of education as a lifelong experience. Teachers and students' perspectives on classroom goals produced a pattern that seemed to indicate that students were more likely to set short-term goals of making good grades. However, teachers were more inclined towards inspiring students to adopt education as a lifelong experience.

\subsubsection{Pursuance of Good Grades}

Student participants described goals that were more academically inclined, with most of them aiming to keep up with good grades and excellent grade point aggregates. Students' goals also appeared more measurable and achievable in the short-term than the goals that teachers endorsed. As student (FB8_2) indicated, "I always want to get $100 \%$ on the test. When I see A's on my report card, I get excited because I know that I can attend a good college after high school." When asked how she was able to achieve that goal, she said, "I study almost every night and I get my homework done on time. I also study well for the test. I pay close attention in class and 1 look back in the book for the answers instead of guessing." AF6_3 expressed similar views but acknowledging his own strengths and weaknesses, he appeared more realistic in his expectations and goals. He stated;

My goal is to get at least grade $\mathrm{C}$ or higher in all my classes. I am not amongst the best students, I know that so I usually study as much as 1 can to make the grades and seeing it on my report card feels great. I try not to get sent to the office and 1 stay quiet in class.

AF7 5's perspectives tied the reason for him to earn good grades to college and career prospects. According to him, good grade pursuit is a precursor for earning a better higher education and future job prospects. He stated;

I want to maintain a 4.0 grade point so far as every class that I am taking is concerned. I try to work and study hard. I am not better in basketball or football because I don't have any of the skills in these activities so if I don't do well in school, I don't know what else I will do. I want to get A's in all my classes, and I don't want to miss homework. I make sure I have my assignments completed on time every day. I know that one day 1 will use everything that I am learning today, and I will get a good job in the future.

Even though some of the teachers acknowledged that they did not know about the goals that their students set, others shared similar experiences with what they knew about their students so far as their classroom goals were concerned. Teachers' perspectives added a dimension to the reasons for students' pursuit of good grades. BT3, a 6th grade teacher who had15years of teaching experience in earth science described;

I know my students always want to earn good grades and get to go to college. The goals of the kids are mainly to pass, have good time, and to hang out with friends. For those who are involved in sports, they want to earn good grades so that they can stay in sports. But most of the time students don't have high academic goals and interests. Going to college might be in the picture but they are more into sports than academics.

The pursuit of good grades merged as an important theme for students who were more academically inclined and those who pursued good grades because of safeguarding their interests in extracurricular activities. In addition, from teachers' perspectives, students pursued other social goals, including making and keeping friends.

\subsubsection{Pursuance of Education as a Lifelong Experience}

Teachers in the study emphasized goals that were meant to shape students' perspectives about how they should see education in general and learning in specific. Although teachers taught different disciplines, they seemed to share similar goal perspectives about wanting their students to focus on education as a lifelong experience. Such perspectives, according to teacher participants, would prepare students to be self-dependent and reliant. AT8, a geography teacher who had 17 years of teaching experience indicated;

I want the kids to have good time and appreciate geography or history or whatever I'm teaching. I want them to have fond memories and say Mr. AT8 made me like geography and history. I want my kids to develop love for learning, country, history, citizenship, reading, and writing and take what they learn to better their lives in future. I don't want them to stop learning. I want my kids to take their prior knowledge and apply to what they are learning.

AT1 who had taught language arts at the sixth grade level for two years explained how she wanted her students to understand who they were and apply that knowledge in transitioning from being dependent to becoming more independent and taking responsibilities. She emphasized;

I have always wanted to guide my students to know that there are opportunities out there but it takes hard work to succeed. I let the kids know that it is okay to make mistakes but they can always improve and they can all become successful. I want my students to become more independent and more personally responsible and not always being told what to do because I see them as always needy and I want them to move from that level of dependence. I want them to 
see themselves in the next ten years and how they hope to get there. Personally, 1 want them to read well, write well, and have love for learning and 1 guess 1 try to let those be their goals as well.

Similarly, AT9 who had facilitated swimming for grades Six through Eight for 9 years explained how she wanted her students to incorporate the general aims of physical education into their day-to-day routines. She shared;

I want those students who are afraid of water to feel comfortable in themselves and their ability to save themselves if there is a life threatening situation. And for those who are comfortable in the water, I encourage them to move from what level of swimming they are at by incorporating water fitness into their daily activities. The overall goal in physical education is to teach students physical activities and how they are going to incorporate them in their daily lives long after they leave us.

\subsubsection{Motivators in the Middle Level Classroom Environment}

The analyses of teachers and students' responses showed an emergence of five main themes: making classroom lessons engaging, positive teacher disposition and personality; personal connection with learning experiences, supportive student-teacher relationships; and varying instructions.

\subsubsection{Making Classroom Lessons Engaging}

Most students in the study shared that they felt bored if they had to sit and watch teachers teach without any social or cognitive engagement. Getting to do activities that revolved around the subject the teacher taught was a major source of motivation to the participants because it helped them to relate to real life situation.

AF6_5, a student shared her perspectives;

I love when we do hands-on project like an experiment in science. I feel that it makes me fully understand and get the concepts. 1 really hate it when we have to sit in the desk a whole hour and sometimes all day and the teacher keeps talking and repeating several times but does not involve activities so that we can also participate in the lesson....I would like teachers to use a lot of activities in the lessons.

Similarly, in recounting his best class, BF8_3 explained;

We did different activities involving moving around, dancing, and jumping. We played a lot of games and activities for learning the concepts and 1 think it was fun. I wished all my other classes were like that because it made it fun and easier to learn. I don't want to sit down and not move for 7 hours a day. If we can do something a little more active in each class, I think I would like school a little better than I do now.

Teachers on their part demonstrated that what made students love learning was how active they were in the teaching and learning experiences. However, according to teacher participants, ensuring students' active engagement in lessons required understanding of whom middle level students were and using that piece of knowledge as a foundation to craft a lesson. BT3 disclosed;

I try to ensure that students are actively engaged. I get them take ownership of the class once they have fun and get them interested in the story or some facts, I think I get them motivated at that point. If I start to lose their attention, I then start with some silliness to keep them going. I also believe that extrinsic motivation doesn't work but the only way they can take anything from class is when they are motivated themselves. My job is to get them fired up somehow. If you can get them listen, take part, they are going to take something away, there is no extrinsic motivation in this world that is going to make them learn. I try to tap in student's value system and encourage them that they can make difference in their own lives and somebody's life by learning those skills.

Another teacher (AT7) also stressed;

Even if I give a lecture which 1 do ones in a while, 1 want them to help me with the lecture by continuously feeding back information to make them active. That is part of the thinking process. It is very important to ensure that students are actively participating in the lesson.

When asked what she did to make students active, she said; "I provide opportunities for students to do project presentations, engage in group work, have fieldtrips, and hands-on activities." In an attempt to explore the significance of creating lessons that made students active participants, BT8 shared; "many middle school students are gamers and they love every activity in the classroom or outside the classroom that comes with games and hands-on." It was noteworthy that in students' estimation, fun and excitement were key to their activeness in the lessons. An $8^{\text {th }}$ grade student from school A stressed, "I like doing projects but I also want to have fun...if the teacher teaches the lesson in a funny way, it makes it exciting and engaging."

\subsubsection{Positive Teacher Disposition and Personality}

Classroom experiences that students and teachers discussed at length were teachers' personality and disposition and 
how those exert influence on students' learning behavior patterns. Specifically, the presence of teachers' personality in teaching and classroom management issues was found to be crucial. In describing his best class, a student pointed out; "The teacher was never strict, she was always in a good mood and she always had something good to talk about and all the kids were excited." AF8_3 expressed similar perspective;

When the teacher finds interesting ways to teach the lesson so that we can get to do something more exciting. When the teacher likes to have fun with the lessons and not being so boring. 1 like crazy and funny teachers. I think crazy teachers get me motivated. If students are happy and laughing they can work better than if they are bored. If the teacher teaches the lesson in the funny way, I get excited and motivated.

Teachers understood how much influence their own dispositions and personalities could influence students' motivation to learn and to strive for excellence. AT6 disclosed;

I help students to build some of the basic skills in math to help them start experiencing success regarding the objectives they already have in math classroom. I don't take myself more serious, but I like to control my class with humor, stories, interesting facts, anything that I could do to get students wrapped in the lesson and feed them with information. I don't just get up there and just say you listen to this and that! But we try to have a silly story that is funny. The kids look forward to coming to class because I'm going to be funny and silly and I think that is a fun thing.

Students in the study used the term a "good teacher" a lot in describing their favorite teacher personality. Students' viewed a good teacher as one who was (a) adept in providing prompt and positive feedback to students' work; (b) funny and creates jokes during instructional activities (c) of high sense of humor, great attitude, and only becomes strict when the need be; (d) one who knows how to get students' attention without yelling at them; (e) caring and offers individualized assistance; (f) one who never gives up on students.

\subsubsection{Supportive Student-Teacher Relationships}

Teachers in the current study considered supportive relationship with students as one key factor that inspired students to succeed. Most teachers implied that getting to know students on a personal level was a key in the design of classroom lessons. According to teacher participants, such relational bond provided students with the opportunity to understand and construct a sense of trust with themselves and their teachers. A teacher emphasized; "If I can win their trust, they would try anything for me. Just getting them to believe in themselves and I also believing in them, they would take that next leap of faith in what I ask them to do." Similarly, AT9 shared;

Children who have fear in water have certain things in common-a lot of insecurity and lack of exposure to water and so I try to organize my lessons where students would have the opportunity to explore in a safe and comfortable environment. Trust is the biggest thing if they trust that I am never going to put them in danger, not going to pull them out of their comfort zone and I am always going to be real positive influence and carry them on, they would try anything for me.

Students also discussed that they felt supported, safe, cared for, and belonged if teachers took special interests in them, and knowing about what they liked and disliked. One important aspect of this relationship that students valued most was a teacher who cared.

\subsubsection{Varying Instructions}

For middle level students in this study, varying classroom instructions stimulated their interest in learning and striving for success. Students shared that they were driven to enjoy learning and understand it if the lesson involved different experiments or games. A student indicated "I like doing projects because when we do different activities or labs on what we are learning it helps me to understand it more because I get to see and feel it instead of just reading about it." Teachers' experiences were not different. Teachers demonstrated a depth of knowledge about who middle level students were and how they could design instructions to meet their learning needs. AT2 indicated;

Students love to hear stories that connect, love to be read to, want to be challenged, don't want to be threatened but to feel comfortable, and they don't want to be doing the same thing every day. Students really like to discuss, like hands-on activities and they want to know why it does matter to learn the things that they learn. I normally ask them what they think of the unit and certain things that would have made the lesson more interesting and the kind of feedbacks I get help me to improve myself as a reflective teacher.

Guided by such foundational knowledge that not all students learned in the same way, most teachers in the study aspired to teach from different ways by trying to do some visual, lecture, and hands-on. AT3 disclosed;

I try to make it fun but at the same time, I want them to build upon what they know so that they can apply it. The kids need to hear again what they have heard already but it has to be a lot of different ways to teach the same thing so that it would look new the next day. You have to try different ways to explain things. I incorporate a lot of hands-on and 
fieldtrips to make my lessons real because students at this stage want to see the real thing.

BT5 shared similar sentiments with the view that a particular lesson could be taught in different ways. He spoke from her own experiences since she taught different sessions of the same grade level. She revealed;

I try to stimulate the lesson in two different ways-visually and auditory. I like making the days look different by using variety of activities. I think it has to be balanced diet for middle school kids especially. Even within one lesson, on average, I make changes three times per class period by switching activities slightly. Students' attention span is not all that great so as much as possible you want to sustain that enthusiasm in the classroom.

BT2 viewed that the fact that students did not learn in the same way was a challenge to reach all students, but at the same time it was an opportunity to think about teaching as an art that required an application of pedagogical creativity.

\subsection{Personal Connection with Learning Experiences}

In the study, most students perceived that their ability to understand lessons depended on how they were personally connected with the classroom experience. In sharing their experiences, most teachers also demonstrated that efforts to motivate students included presentations of instructions in a manner that had personal significance and connections with the academic and social needs of students. BT1 was a Seventh grade mathematics teacher and has had 33 years of teaching. She tried to make learning fun for the kids by using activities that students could relate well with which according her gave students the reasons to want to learn. To connect classroom lesson to students' needs', AT2 shared;

My students love to hear stories and connections and I try to connect every lesson with something they can easily identify with. I have to watch the movies that they watch, listen to music they listen to so that 1 can help them connect what they learn with those movies and music they watch and listen to.

Similarly, AT1used personal stories to reach and connect to students. She indicated;

I see students as story-hearing lovers so I try to incorporate a lot of personal stories in my lessons. Stories that they can personally connect with what they learn. I believe students' motivation ought to come from within and as a teacher, I only help them develop love for reading. The motivation could start externally but then should end up helping them develop the inner attitude for learning.

BT2 thought that getting students to get the personal connection with lesson activities was what drove students' active engagement as well. She specified;

The personal connection that I am able to make at the very beginning of every unit makes the whole difference. I try to have students to get that personal connection with what they learn and once they are personally connected to the concepts, they think back on what we did at the beginning of that unit. If they don't personally get connected to what I teach, it would not be meaningful to them. I think that the important thing I do to make them like to come to my class is that 1 try to make the materials personally meaningful to them.

\section{Discussions and Implications}

Middle level classroom goal orientations endorsed by teachers and students have important motivational framework implications, particularly in influencing school-related successes. In the study, good grade pursuits marked the goal orientations of most students. In some instances, social, economic, and other cultural circumstances could be inferred from the reasons students cited for wanting to earn good grades. Students' goal perspectives were more consistent with performance orientation, with a range of normative, as well as avoidance approaches. The findings reflected similar results from previous large scale longitudinal studies that showed that middle level classroom goals were more performance related and less mastery related (Anderman \& Midgley, 1997; Urda \& Midgley, 2003). However, teachers' goal perspectives indicated a range of both mastery and performance orientations. Teachers influenced students to align their personal and academic goals to reflect a long-term view of learning and education. However, the challenge is that current conditions of increased demand for performance accountability pose a challenge for students to re-orient their classroom goals that reflect goals that are mastery-focused or the consideration of learning as a lifelong experience. Under the current wave of standardized reforms, students' academic gains and successes are more aligned with standardized test outcomes. With the widespread implementation of the common core standards across states in the U.S., teachers and administrators are increasingly growing concerned about the fact that standardized testing is largely driving classroom instructions (Karp, 2013). In such test-driven learning environments, target for improving students' tests scores becomes a priority. The effect is that if students perceive that the measurement of their achievement outcomes is based on the comparative abilities and tests outcomes, they are more likely to adopt performance oriented goals (Meece, Anderman, \& Anderman, 2006; Deemer, 2004).

Teacher participants endorsed that students rather pursue education as a lifelong experience rather than just focusing on making good grades. Reorienting middle level classroom goal structure to change students' learning attitudes requires 
the incorporation of best practices in classroom routines. These routines should guide students to set standards for their own performance, not in terms of how others perform but viewing the development of new skills as a necessary outcome of their learning tasks. Teachers' instructional, evaluation, and grouping strategies should increase opportunities for students to develop a sense of personal control and ownership in the decisions about classroom learning activities and assignments (Ames, 1992; Meece, Anderman, \& Anderman, 2006). One way to encourage students' ownership is to give them the opportunity to make choices about what partners to work with during collaborative tasks, the materials to use, and how to complete classroom projects (Ames, 1992).With the use of classroom incentives and praise, attention should be paid to individual progress, effort, and improvement, while limiting the use of comparative ability assessment criteria (Deemer, 2004; Ames, 1992). Teachers need to demonstrate to students the diverse ways to master course content by varying instructional activities and methods to appeal to different styles and abilities.

\subsection{Motivating Middle Level Students to Achieve Their Learning Goals}

Every goal-oriented teacher wishes to have students who are overly enthusiastic, stay active in the classroom, actively cope with challenges, and persist in the face of difficulties. However, these attitudes rarely occur naturally with middle level students. Creating a quality classroom environment for middle level students continues to attract the attention of educators and researchers (Midgley \& Maehr, 1994; Meece, Anderman, \& Anderman, 2006; Meece, 2003; Wentzel, 1997; Ryan \& Patrick, 2001). Almost all teacher participants implied that creating a classroom environment that drives students to be successful is part of their professional duties, yet it is a challenging task. In this section, we discuss the five themes about motivation that emerged from the analyses of the data.

Increasing opportunities for student active participation in lessons drive young adolescents to explore their vibrancy and curiosity. However, limited emphasis has been placed on the consideration that both students and teachers are active participants in the classroom who jointly construct meaning and understanding (Mara, 2005). Meece (2003) discussed the need to incorporate learner-centered approach (LCP) into the instructional and curriculum reform initiatives that affect middle level environment. The LCP is a constructivist approach to classroom activities with emphasis on students' responsibilities and initiatives in determining learning goals and regulation of their efforts toward such goals (Mara, 2005). Middle level teachers' adoption of LCP can create opportunities for shared decision process in the classroom, with students having the sense of ownership and responsibility towards their learning. Middle level classroom requires a structure that places students' interests, learning styles, and self-concepts at the center of classroom instructions. Chances are that in leaner-centered learning environments, students can develop conceptual and analytic thinking skills through collaboration and cooperation with other students who have different learning abilities and diverse cultural backgrounds. Classroom experiences that limit students' chances of engaging in varying activities creates a controlling system that suppresses students' inner tendencies, capacities, and desires to challenge themselves academically (Knowles \& Brown, 2000). Middle school students, by their nature, need to find constructive expression for their inherent curiosity. Teachers need to use multiple instructional strategies that inspire students to take on challenging and hands-on assignments and practice new skills (Haselhuhn et al., 2007). Developmentally responsive learning environment should view students as having unique characteristics. Activities should be planned to allow students to build on their own uniqueness by constructing and developing new interests, goals, and skills. Such activities should be purposeful, intrinsically driven, goal-oriented, and suspense-driven to continually hold students' attention in the lessons.

It is worth noting that students' perceptions of teacher positive disposition and support emerged as a major motivational factor in the middle level classroom. As perceived by student participants, a supportive teacher is one who; provides prompt and positive feedback to students, identifies and incorporates students' learning needs in instructional activities, has a sense of humor, is fair in determining learning outcomes, knows how to get students' attention without yelling at them, cares and offers individualized assistance, and does not give up on students. Consistent with previous findings, the pattern of middle level students' perceptions of supportive teacher has not changed much over the years (Wlodkowski 1997; Wentzel, 1997; Ryan \& Patrick, 2001). For instance, in a longitudinal study about how middle level students characterized a caring and a supportive teacher, Wentzel (1997) found that students' perceptions showed that a caring teacher was one who demonstrates democratic interaction styles, gives constructive feedback, develops varying expectations for students, models caring attitude toward students' classroom work. Both Wentzel (1997) and Ryan and Patrick (2001) also found positive relationships between students' perceptions of teacher support and changes in their motivation and academic engagement, with increased pursuit of prosocial and social responsibility goals. The current findings echo the consideration of students' perceptions of teacher disposition in the construction of motivational framework that can shape instructional variables. Students' perception of teacher classroom instructional abilities, values, beliefs, and expectations can influence the quality of students' effort and engagement in the classroom. Even though it was not clear in the study how such teacher traits were connected with students' interests and engagement, we 
can speculate that teacher traits such as humor, care, and openness could be applied to diffuse classroom tensions, especially in behavior management situations.

In addition, the findings of the study have demonstrated an understanding that middle level students' motivation to learn can be enriched by the extent to which classroom experiences are connected with students' needs. Improving middle level education requires the creation of a learning environment that is supportive in meeting the developmental needs of young adolescents. Within such an environment, not only teachers need to understand the developmental uniqueness of young adolescents, but it is also important for them to apply such understanding in the design of instructions that connect students' social, cultural, and physical world. Middle school students, at this age, tend to question, either explicitly or implicitly, about the value of what they learn and how they learn it. They may want to know why and how the knowledge relayed to them is useful and how it relates to their world of understanding. Knowles and Brown (2000) observed that by increasing opportunities for authentic learning, students can connect curricula to events occurring in their lives. Authentic learning emotionally engages students, as they use the information in real life contexts that have meaning to them. Examples may include student-generated activities such as developing oral presentations to explain research findings, constructing timelines, creating slide shows, writing song lyrics, creating maps, submitting a short story of publication in a local journal, or devising a plan. These activities, according to Knowles and Brown, demonstrate how young adolescents are able to use most of their developing cognitive skills such as creative thinking and problem solving rather than merely memorizing isolated facts, as it is the case with many standardized and teacher-designed assessments.

Again, the study found that supportive classroom relationships, particularly between teachers and students are crucial in attending to the motivational needs of middle level students. Such trusting relationships allow students to develop mutually-responsive attitudes, adopt safe feelings, willingness to take risks, and demonstrating the desire to participate in their learning. Juvonen (2007) found that of all the various forms of school-based social relationships, teachers' support appeared the most crucial. When teachers show their acceptance of students and students also begin to see and understand that teachers care, school can be mutually satisfying to both students and teachers. Central to the quality of student-teacher relationships is the belief that students bring to the classroom their mental schemes of understanding the nature of their social world and relationships, as they seek genuine support in such relationships. Teachers have opportunities to demonstrate a model of genuine interests and care by trying to understand why sometimes young adolescents behave the way they do. A very key component of any classroom relationship is the level of trust particularly held by students. Taking time to know what students' likes and dislikes are, what their hobbies are, and even start talking about their little dog at home that they love so much could sometimes be all that the teacher needs to be able to help students allay their anxieties and uncertainties toward school successes.

\section{Conclusion}

As educators continue to discuss and debate the best way to meet the educational needs of middle level students, directing efforts to creating a learning environment that is based on the knowledge about middle level students, their classroom goal pursuits, and what they might consider as "motivators" is crucial. Teachers' knowledge of the developmental characteristics of middle level students is a foundation to understanding classroom experiences that teachers can create to motivate students to improve their learning outcomes. Some students appear naturally enthusiastic about learning. However, many of them need and expect their teachers to inspire, challenge, and stimulate their interest and enthusiasm. The quality of students' effort and engagement in their learning environment is crucial. Subject to the continual changes in the material content covered and the social contexts within which classroom instructions are carried out, students are often involved in unfamiliar learning situations (Boekaerts, 2002). Such conditions create opportunities to create classroom experiences based on the knowledge about student beliefs, values, backgrounds, and other characteristics. While most teachers find such tasks as complex and challenging, findings of the study indicate that it is achievable in an environment where; both teachers and students are active participants, knowledge about students' uniqueness informs classroom pedagogy, students have opportunities to relate learning experiences to their world of understanding, and students feel loved, cared for, and encouraged to use their curiosity to explore challenging learning experiences. Consistent provision of these experiences in the middle level classroom gives us the reason to be optimistic that all students can meet their learning goals in a motivating manner. A teacher participant perhaps said it better "...all students can learn, for the number of years I have taught, I have not found a single student who cannot learn". If "...middle school education aims at producing intellectually reflective persons, individuals enroute to a lifetime of meaningful work, good citizens, caring and ethical individuals, and healthy persons" (Jackson \& Davis, 2000, p. 22), both their short and long-term achievements will be dependent on the quality of learning experiences created in the classroom. 


\section{Limitation and Future Directions}

While the study highlighted some important perspectives of students and teachers on middle level classroom goal pursuits and motivation, it was not without limitations. First, the study was a qualitative study and as such the transferability of the findings was limited within contexts that exhibit similar features. Second, the construct of student motivation relates to many factors, including psychological, social, and other cultural factors. These factors are interconnected and they influence a range of goals, beliefs, and attitudes about how students approach learning (Ames, 1992). Creating in-depth understanding might therefore require an exploration of a range of experiences. For instance, Iyengar and Lepper (1999) reported that Anglo American children were less intrinsically motivated when choices were made for them by others than when they made their own choices, while Asian American children were most intrinsically motivated when choices were made for them by trusted authority or peers. However, the convenient sample used in the study did not allow for the inclusion of teachers and students who had diverse cultural background, regarding race, ethnicity, country of origin, and gender. The potential influence of the cultural landscape on participants' perceptions was not adequately accounted for. Future inquiry may focus on how these cultural traits mediate students and teachers' motivational beliefs.

\section{References}

Ames, C. (1992). Classrooms: Goals, structures, and student motivation. Journal of Educational Psychology, 84, 261271. http://dx.doi.org/10.1037/0022-0663.84.3.261

Anderman, E., \& Maehr, M. (1994). Motivation and schooling in the middle grades. Review of Educational Research, 64, 287-309. http://dx.doi.org/10.3102/00346543064002287

Anderman, E., \& Midgley, C. (1997). Changes in achievement goal orientations, perceivedacademic competence, and grades across the transition to middle-level school. Contemporary Educational Psychology, 22, 269-298. http://dx.doi.org/10.1006/ceps.1996.0926

Boekaerts, M. (2002). Motivation to learn. Report No. IAE/IBE-Ser-10. Geneva, Switzerland: International Bureau of Education. Eric Document Reproduction Service No. ED470681.

Brophy, J. (2005). Goal theorists should move on from performance goals. Educational Psychologist, 40(3), 167-176. http://dx.doi.org/10.1207/s15326985ep4003_3

Bruning, R., \& Horn, C. (2000). Developing motivation to write. Educational Psychologist, 35(1), 25-37. http://dx.doi.org/10.1207/S15326985EP3501_4

Casas, M. (2011). Enhancing student learning in middle school. New York: Routledge.

Charmaz, K. (2011). Constructivist grounded theory analysis of losing and regaining a valued self in Wertz, F. J., Charmaz, K., McMullen, L. J., Josselson, R., Anderson, R., and McSpadden, E., (eds) Five ways of doing qualitative analysis: Phenomenological psychology (pp.165-2000). NY: The Guilford Press.

Daniels, E., \& Steres, M. (2011). Examining the effects of a school-wide reading culture on the engagement of middle school students. Research in Middle Level Education Online, 35(2), 1-13.

Davis, B. (1993). Tools for teaching. San Francisco: Jossey-Bass.

Deemer, S. A. (2004). Using achievement goal theory to translate psychological principles into practice in the secondary classroom. American Secondary Education, 32(3), 4-16.

Eccles, J. S., Lord, S., \& Midgley, C. (1991). What are we doing to adolescents? The impact of educational contexts on early adolescence. American Journal of Education, 99, 52-542. http://dx.doi.org/10.1086/443996

Eccles, J. S., \& Wigfield, A. (1997). Teaching/Learning. In J. L. Irvin (Ed.), What current research says to the middle level practitioners (pp.15-29). Columbus, OH: National Middle School Association.

Elliot, A. J. (1999). Approach and avoidance motivation and achievement goals. Educational Psychologist, 34, 169-189. http://dx.doi.org/10.1207/s15326985ep3403_3

Elliot, A. J., Murayama, K., \& Pekrun, R. (2011). A $3 \times 2$ achievement goal model.

Journal of Educational Psychology, 103, 632-648. http://dx.doi.org/10.1037/a0023952

Erwin, C. J. (2004). The classroom of the choice: Giving students what they need and getting what you want. Alexandria: Association for Supervision and Curriculum Development.

Giorgi, A. (2007). Concerning the phenomenological methods of Husserl and Heidegger and their application in psychology collection. $d u$ Cirp, 1, 63-78. 
Good, T., \& Brophy, J. (1995). Contemporary educational psychology, (5th edition). New York: Longman.

Harackiewicz, J. M., Barron, K. E., Pintrinch P. R., Elliot, A. J., \& Thrash, T. M. (2002). Revision of achievement goal theory: Necessary and illuminating. Journal of Educational Psychology, 94(3), 638-645. http://dx.doi.org/10.1037/0022-0663.94.3.638

Haselhuhn, C. W., Al-Mabuk, R., Gabriele, A., Groen, M., \& Galloway, S. (2007). Promoting positive achievement in the middle school: A look at teachers' motivational knowledge, beliefs, and teaching practices. Research in Middle Level Education Online, 30(9), 1-20.

Hlebowitsh, P. S. (2001). Foundations of American education. New York: Wadsworth

Iyengar, S. S., \& Lepper, M. R. (1999). Rethinking the value of choice: A cultural perspective on intrinsic motivation. Journal of Personality and Social Psychology, 76(3), 349-366. http://dx.doi.org/10.1037/0022-3514.76.3.349

Jackson, A., \& Davis, G. (2000). Turning Points 2000: Educating adolescents in the $21^{\text {st }}$ century. New York: Teachers College Press.

Juvonen, J. (2007). Reforming middle schools; Focus on continuity, social connectedness, and engagement. Educational Psychologist, 42(4), 197-208. http://dx.doi.org/10.1080/00461520701621046

Karp, S. (2013). The problems with the common core. Rethinking schools, 28(2).

Knowles, T., \& Brown, F. D. (2000). What every middle school teacher should know. Portsmouth: Heinemann.

Kouzes, J., \& Posner, B. (2002). The leadership challenge. San Francisco: Jossey-Bass.

Leedy, P. D., \& Ormrod, J. E. (2005). Practical research: Planning and design (8th ed.). Upper $\quad$ Saddle River, NJ: Prentice Hall.

Lincoln, Y. S., \& Guba, E. G. (1985). Naturalistic inquiry. Beverly Hills, CA: Sage.

Lounsbury, H. J. (1997). Foreword. In J. L. Irvin (Ed.). What current research says to themiddle level practitioners (pp xi-xii). Columbus, OH: National Middle School Association.

Mara, R. (2005). Teacher beliefs: the impact of the design of constructivist learning environments on instructor epistemologies. Learning Environments Research. 8,135-155. http://dx.doi.org/10.1007/s10984-005-7249-4

Martin, J. A., \& Dowson, M. (2009). Interpersonal relationships, motivation, engagement, and achievement: Yields for theory, current issues, and educational practice. Review of Educational Research, 79(1), 327-365. http://dx.doi.org/10.3102/0034654308325583

Maxwell, J. (2008). Designing a qualitative study.” In L Bickman and DJ Rog (Eds.), The hand book of applied social research methods, ( $2 \mathrm{n}$ ed.). Thousand Oaks CA: Sage Publications.

McCombs, B. L., \& Pope, J. E. (1994). Motivating hard to reach students. American Psychological Association: Washington DC. http://dx.doi.org/10.1037/10151-000

Meece, J. L. (2003). Applying learner-centered principles to middle school education. Theory into Practice, 43(2), 109-116. http://dx.doi.org/10.1207/s15430421tip4202_4

Meece, J., Anderman, E. M., \& Anderman, L. H. (2006). Classroom goal structure, student motivation, and academic achievement. Annual Review of Psychology, 57, 505-528. http://dx.doi.org/10.1146/annurev.psych.56.091103.070258

Midgley, C., Anderman, E., \& Hicks, L. (1995). Differences between elementary and middle school teachers and students: A goal theory approach. Journal of Early Adolescence, 15, 90-113. http://dx.doi.org/10.1177/0272431695015001006

Midgley, C., \& Maehr, M. L. (1994). Motivation and schooling in the middle grades. Review of Educational Research, 64 (2) 287-309. http://dx.doi.org/10.3102/00346543064002287

Midgley, C., \& Urdan, T. (2001). Academic self-handicapping and achievement goals: A further examination. Contemporary Educational Psychology, 26, 61-75. http://dx.doi.org/10.1006/ceps.2000.1041

Muraya, K., \& Elliot, A. J. (2009). The joint influence of personal achievement goals and classroom goal structures on achievement-relevant outcomes. Journal of Educational Psychology, 101(2), 432-447.

National Middle School Association (2003). This we believe: Successful schools for young adolescents. Westervilee, OH: Author.

Pintrich, P. R. (2001). The role of goal orientation in self-regulated learning. In M. Boekaerts, P. R. Pintrich，\& M. 
Zeidner (Eds.), Handbook of self-regulation ～(pp.451-502). San Diego: CA, Academic Press.

Pintrich, P. R., \& Schunk, D. H. (2002). Motivation in education: Theory, research, and applications (2nd ed.). Upper Saddle River, NJ: Merrill Prentice Hall.

Roeser, R. W., \& Eccles, J. S. (1998). Adolescents' perceptions of middle school: Relation to longitudinal changes in academic and psychological adjustment. Journal of Research on Adolescence, 8, 123-158. http://dx.doi.org/10.1207/s15327795jra0801_6

Ryan, A. M., \& Patrick, H. (2001). The classroom social environment and changes in adolescents' motivation and engagement during middle school. American Educational Research Journal, 38, 437-460. http://dx.doi.org/10.3102/00028312038002437

Skinner, E. A., \& Belmont, M. J. (1993). Motivation in the classroom: Reciprocal effects of teacher behavior and student engagement across the school year. Journal of Educational Psychology, 85, 571-581. http://dx.doi.org/10.1037/0022-0663.85.4.571

Stipek, D. (2002). Motivation to learn: Integrating theory and practice. Boston: Allyn \& Bacon/Longman.

Urdana, T., \& Midgley, C. (2003). Changes in the perceived classroom goal structure andpattern of adaptive learning during early adolescence. Contemporary Educational Psychology, 28, 524-551. http://dx.doi.org/10.1016/S0361-476X(02)00060-7

van Menam, M. (1990). Phenomenology of practice. Phenomenology \& Practice, 1 (1), 11 - 30.

Wentzel, K. R. (1997). Student motivation in middle school: The role of perceived pedagogical caring. Journal of Educational Psychology, 89, 411-419. http://dx.doi.org/10.1037/0022-0663.89.3.411

Wentzel, K. R. (1999). Social-motivational processes and interpersonal relationships: Implications for understanding students' academic success. Journal of Educational Psychology, 91, 76-97. http://dx.doi.org/10.1037/0022-0663.91.1.76

Wentzel, K. R., \& Wigfield, A. (2007). Introduction to motivation at school: Interventions that work. Educational Psychologist, 42(4), 191-196. http://dx.doi.org/10.1080/00461520701621103

William-Boyd, P. (2003). Overview. In P. William-Boyd, (Ed.). Middle grades education, (pp.451-502). San Diego: CA, Academic Press.

Wolters, C. A. (2004). Advancing achievement goal theory: Using goal structures and goal orientations to predict students' motivation, cognition, and achievement. Journal of Educational Psychology, 96 (2), 236-250. http://dx.doi.org/10.1037/0022-0663.96.2.236

Wolters, C. A., \& Daugherty, S. G. (2007). Goals structures and teachers' sense of efficacy: Their relation and association to teaching experience and academic level. Journal of Educational Psychology, 99 (1), 181-193. http://dx.doi.org/10.1037/0022-0663.99.1.181

\section{(cc) $\mathrm{BY}$}

This work is licensed under a Creative Commons Attribution 3.0 License. 